\title{
CONSTRUCTION AND PERFORMANCE EVALUATION OF A CENTRIFUGAL MILK SEPARATOR
}

\author{
El-Sharabasy M. M. A. ${ }^{1}$ \\ M. M. Badr' \\ E. M. Abdel-Wahed ${ }^{3}$
}

ABSTRACT

The aim of the present study is to construct and evaluate a centrifugal milk separator for cream and skim milk production. The milk separator consists of five main parts: power source, transmission system, collection milk vessel, centrifugal separation unit and production collectors. The centrifugal separation unit consists of three parts: housing, separated discs with totally number of 40 conical discs collect and fix in the housing together and stuck base, which fastening the conical discs and the housing together through a stud and Hex. Hd. Nut. Laboratory experiments were conducted to optimize milk feeding rate, separation rotating speed and raw milk temperature degree. While the separator performance was evaluated in terms of cream and skim milk amounts, skim milk fat percentage, separation efficiency, specific energy and operational cost of milk separation. The experimental results reveal that the milk separator is recommended to be used under the following conditions to give the highest cream amount of 35 $\mathrm{kg} / \mathrm{h}$ with lower specific energy and operational cost of $25.14 \mathrm{~kW} . \mathrm{h} / \mathrm{Mg}$ and 228.60 L.E/Mg, respectively:

- Milk feeding rate to the conical separating unit of $400 \mathrm{~kg} / \mathrm{h}$.

- Separation rotating speed of 8000 rpm.

- Temperature degree for the raw milk of $37^{\circ} \mathrm{C}$.

\section{INTRODUCTION}

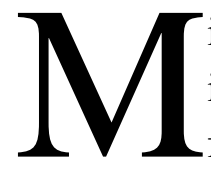

ilk is the oldest and at the same time most natural "energy drink" in the world. Alongside the health aspect is the enjoyment factor. New specialists, not least in quark and soft cheese products or flavored drinks, have resulted in chiller cabinets for dairy products becoming larger than ever. The major components of raw milk are water, fat, protein, lactose and minerals. These components can be influenced by many factors, including genetics and nutrition.

\footnotetext{
${ }^{1}$ Assist. Prof. of Agric. Eng., Fac. of Agric., Zagazig Univ., Egypt.

${ }^{2}$ Lecturer of Agric. Eng., Fac. of Agric., Zagazig Univ., Egypt.

${ }^{3}$ Lecturer of food science, Fac. of Agric., Zagazig Univ., Egypt.
} 
Cream is prepared from milk by centrifugal separation. United States standards require cream containing a minimum of $36 \%$ fat to be labeled "heavy whipping" cream. Cream used as an ingredient contains $36 \%$ to $40 \%$ fat. By standardizing with skim milk, cream of different fat levels can be produced. Light whipping cream and light ("coffee" or "table") cream contain $30 \%$ to $36 \%$ and $18 \%$ to $30 \%$ fat, respectively. Specific homogenization and heat treatments bring about desirable grades of viscosity in cream products. Cream should be stored under refrigeration. It can be quick-frozen and stored frozen until used. (According to DMI, 2005). Burgess (1991) stated that the modern dairy separator will separate virtually all fat globules larger than $0.8 \mu \mathrm{m}$, and because most of the milk fat is present in the form of such globules, it is relatively easy to separate the bulk of the milk fat. Fat globules below $0.8 \mu \mathrm{m}$ are generally referred to as no separable globules. Tetra Centri (2003) reported that the cold milk separation at $4-8{ }^{\circ} \mathrm{C}$ is the alternative when heating milk is undesirable. Cream's viscosity and characteristics at low temperatures make the AirTight technology the only feasible form of separation for this task. The fat content of the skim milk can vary between $0.1-0.2 \%$ and the maximum fat content of the cream at $40{ }^{\circ} \mathrm{F}$ is generally $42 \%$. The hot milk can be also separated the globular milk fat from the serum, the skim milk. The separation process is normally incorporated into a pasteurization line and combined with a Tetra Alfast in-line fat standardization system. Outgoing cream from Tetra Centri Air-Tight separators can contain up to $70 \%$ fat. The skimming efficiency of hot milk separators has been enhanced. In a modern dairy, common Tetra Centri skimming efficiency figures are in the range of 0.045-0.06\%. Endress and Hauser (2008) found that after the initial heating of the raw milk in the first regenerator section of the HTST, the raw, whole milk, containing approximately $3.6 \%$ fat, is separated into a cream phase and a skim milk phase with a constant fat content. To reach the desired fat content of the cream, a controlled flow rate of skim milk enters the cream line in the separator. Cream is usually standardized from $35 \%$ to $50 \%$ fat. Standardized cream can then be remixed with the skim after the separator. The flow rate of the remixed, standardized cream with the skim phase determines the final milk standardization (1-2\%). If none of the standardized cream is remixed, the final product is skim milk. Westfalia 
(2010) reported that raw milk contains around 4 percent fat. In order to produce non-fat milk, this cream must first be separated. Here, a differentiation is made between warm milk separation at temperatures between 50 and $60{ }^{\circ} \mathrm{C}$ and cold milk separation, which takes place at temperatures between 4 and $30{ }^{\circ} \mathrm{C}$. A vertical centrifugal separator supports both these processes. For locally milk, this means the lowest possible feed pressure, gentle product intake, the lowest possible shearing forces and therefore the highest possible separation efficiency. Atia et al. (2012) reported that the centrifugal separation is a very common process in dairies. A centrifugal separator consists of a stack of discs in a rotating bowl. The entering milk is accelerated to the same speed of rotation as the bowl and is distributed in the separation channels between the discs. The cream, having a lower density than skimmed milk, moves inwards towards the axis of rotation, whereas the skimmed milk moves outwards to the space outside the disc stack. The two fractions are then discharged from the separator through separate outlets. In most dairies the cream separation is carried out by means of self-cleaning separators. The milk is separated into a stream of cream containing $40 \%$ fat and a stream of skimmed milk containing $0.04-0.07 \%$ fat. The separator also discharges sediment consisting of dirt particles, udder cells, bacteria, leucocytes, etc., which is normally carried to the drain. The total amount of sediment in milk is normally about $1 \mathrm{~kg} / 10,000$ liters. The separator is usually connected to the preheating section of the pasteurizer, as the optimum temperature for separation is about $65^{\circ} \mathrm{C}$. Westfalia (2012) reported that the centrifugal of cream concentrators are directed towards the following: a) attainment of a high cream fat content, b) maximum separating efficiency to achieve the lowest residual fat content in the discharging heavy phase and c) fast and precise partial solids ejection from the bowl in order to minimize fat losses. The $40 \%$ cream to be concentrated is fed through the central feed tube with a certain flow velocity into the inlet chamber, which rotates at the same speed as the bowl. The energy of flow in the stationary feed tube is converted into pressure energy in the optimally widened inlet chamber (principle of the soft-stream system). Kenana online (2013) reported that, the factors which can be affected the percentage of fat in the cream and fat losses of in the skim milk were; a) Separator rotating speed: the percentage of fat in the cream increases as the separation rotating speed 
(centrifugal force) is increasing. B) The temperature of raw milk: the most suitable temperature to skim milk ranging between $29-43^{\circ} \mathrm{C}$. c) Feeding rate of raw milk in the separator cone: If the feeding rate of entry milk to the separator increased, the separation efficiency decreased due to lack of centrifugal force acting on milk and therefore can not be separated fat efficiently from the raw milk and increases the loss of fat in the skim milk and also increases the amount of cream and less than fat. Meshref (2013) mentioned that most farmers milk their cows and buffaloes manually and separate milk into cream and skimmed milk. The skimmed milk is used to manufacture Kareish cheese, while the fresh cream is stored at room temperature in a one-piece goatskin bag to make butter.

So, the objectives of this study are to:

- Construct a vertical milk separator to be suitable for separating the cream from the raw milk.

- Optimize some operating parameters: milk feeding rate, separation speed by centrifugal force, and temperature degree of the raw milk affecting the performance of the milk separator.

- Evaluate the milk separator from the economic point of view.

\section{MATERIALS AND METHOD}

This study was carried out through the during the summer season of 2013 at Agricultural Engineering Department and Food Science Department, Faculty of Agriculture, Zagazig University to construct and evaluate the performance evaluation of a centrifugal milk separator for cream skimming from raw milk.

\subsection{MATERIALS:}

2.1.1. Raw milk: Fat full milk used to separate cream from raw milk was gathered from local buffalos in Abo Al-Akhdar village, Sharkia Governorate. The milk fat exists as small globules or droplets dispersed in the milk serum. Their diameters range from 0.1 to $20 \mu \mathrm{m}$. The average size is $3-4 \mu \mathrm{m}$ and there are some 15 billion globules per $\mathrm{ml}$. As the fat globules are not only the largest particles in the milk but also the lightest density at $15.5^{\circ} \mathrm{C}=0.93 \mathrm{~g} / \mathrm{cm}^{3}$. They tend to rise to the surface when milk is left to stand in a vessel for a while. But the small size of the fat globules makes creaming a slow process. 
2.1.2. Constructed milk separator: The constructed milk separator was manufactured from low cost and local materials to overcome the problems of high cream loss percentage in skim milk and the low overall separator efficiency under the use of the other separators. The centrifugal milk separator was manufactured specially for this work and constructed at a private workshop in Sharkia Governorate as shown in Fig.1 and Photo 1. The constructed milk separator consists of the following parts:

2.1.2.1. Power source: An electric motor with rated power of $1.10 \mathrm{~kW}$ $(1.50 \mathrm{hp})$ at a rated speed of $1500 \mathrm{rpm}$ was used to operate the milk separator by means of pulleys and V-belt.

2.1.2.2. Transmission system: The rotating motion of the electrical motor was transported to the vertical separation unit using V-belt and two pulleys: the first one located on the electrical motor shaft with changeable diameters of $45,55,6.5$ and $75 \mathrm{~mm}$, while the second one located on the separation unit shaft with constant diameter of $150 \mathrm{~mm}$.

2.1.2.3. Collection milk vessel: a collection milk vessel was made from aluminum with whole diameter at the top end of $530 \mathrm{~mm}$ and depth of $280 \mathrm{~mm}$ to receive the worm milk at treatment temperature. The collection milk vessel is steady on a circular metal base and has a tap located at the front side directly over the inlet gate of the stuck discs. The inlet gate has aluminum float to adjust the worm milk feed rate entering to the disc stuck.

2.1.2.4. Centrifugal separation unit: called (Stuck discs), which consists of three parts: the first part is the housing or the cover made of steel with conical in shape (large diameter of $160 \mathrm{~mm}$, small diameter of $50 \mathrm{~mm}$ and height of $90 \mathrm{~mm}$ ). The second part is the separated discs with totally number of 40 conical discs collect and fix in the housing together. Each disc has three holes with $10 \mathrm{~mm}$ diameter located at the circumference of the disc from the upper side. The third part is the stuck base, which fastening the conical discs and the housing together through a stud and Hex. Hd. Nut.

2.1.2.5. Productions collectors: during the milk separator is operating, the cream comes out from the disc stuck to the cream out let and the skim milk comes out from the disc stuck to the skim milk out let. Each out let is delivering its product through a runway to a special container.

2.1.2.6. Frame: the milk separator has a special rectangular frame with three stands to carry all milk separator components. This frame has metal base with dimensions of $850 \mathrm{~mm}$ in length, $320 \mathrm{~mm}$ in width and $40 \mathrm{~mm}$ in thickness. 
PROCESS ENGINEERING
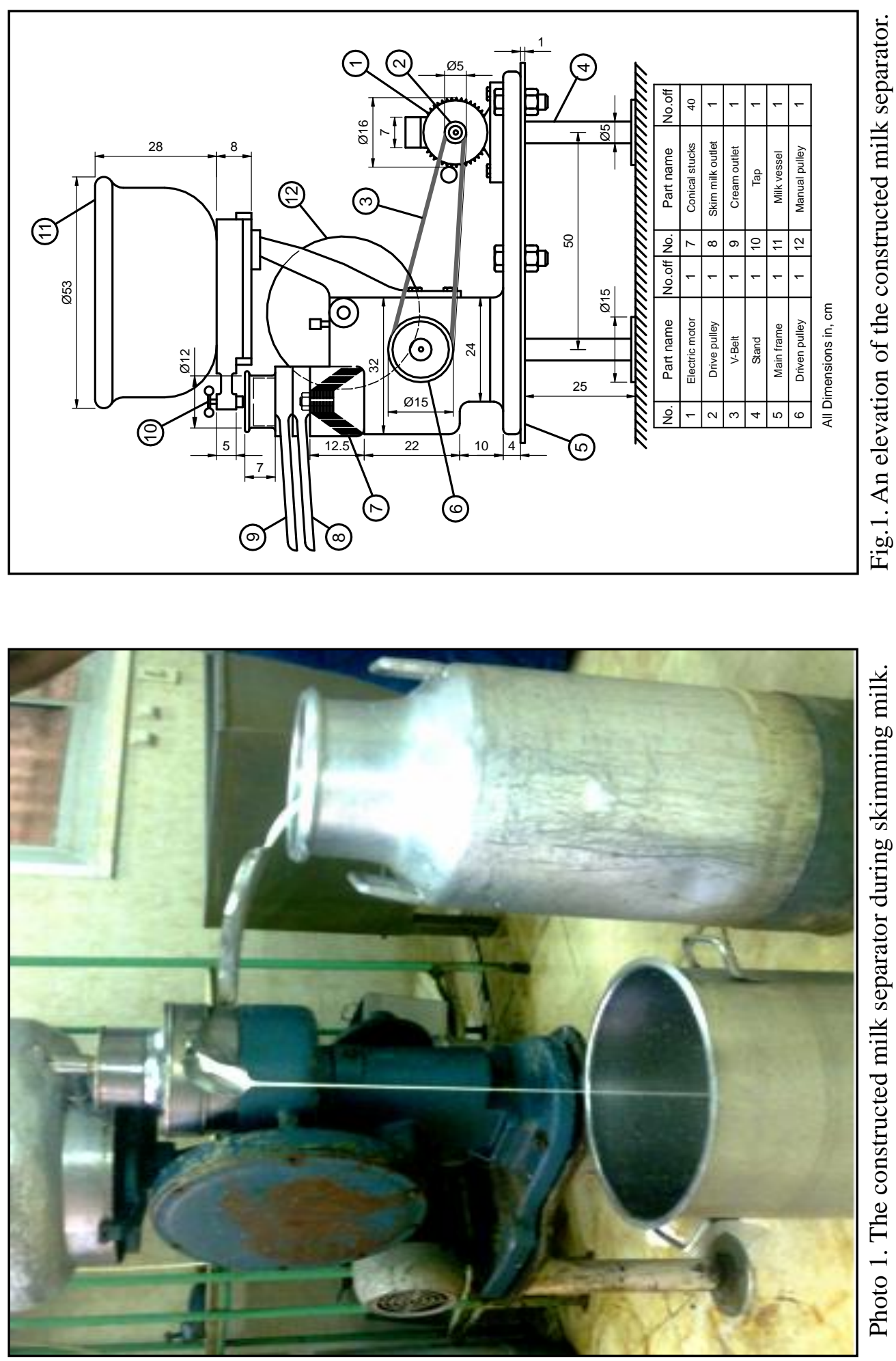

Misr J. Ag. Eng., October 2013 
2.2.1. Physical properties of milk: in recent years, there has been a general recognition of the need to determine the physical and engineering characteristics of milk. This characteristics are used to design and manufacture different machines or in the analysis of the behavior of the product in handling of material. In this study some physical and engineering properties of milk were either measured or calculated. A random sample of $5.00 \mathrm{~kg}$ was taken from raw milk to obtain data on some physical properties such; as appearance, density and acidity.

2.2.1.1. Appearance: the opacity of milk is due to its content of suspended particles of fat, proteins and certain minerals. The color varies from white to yellow according to the coloration (carotene content) of the fat. Skim milk is more transparent, with a slightly bluish tinge.

2.2.1.2. Density: the density of milk normally varies between 1.028 and $1.038 \mathrm{~g} / \mathrm{cm}^{3}$ depending on the composition. The density of milk at 15.5 ${ }^{\circ} \mathrm{C}$ can be calculated according to following formula:

$$
\rho=\frac{100}{F / 0.93+\mathrm{SNF} / 1.608+\text { Water }}, \quad \mathrm{g} / \mathrm{cm}^{3}
$$

Where: $\mathrm{F}=$ Fat in milk, $\%$.

$\mathrm{SNF}=$ Solids non fat, $\%$.

Water, $\%=100-\mathrm{F}-\mathrm{SNF}$.

2.2.1.3. Acidity: the acidity of a solution depends on the concentration of hydronium ions $\left[\mathrm{H}^{+}\right]$in it. When the concentrations of $\left[\mathrm{H}^{+}\right]$and $[\mathrm{OH}]$ (hydroxyl) ions are equal, the solution is called neutral $\mathrm{pH}$ represents the hydronium ion concentration of a solution and can mathematically be defined as the negative logarithm of the hydronium ion $\left[\mathrm{H}^{+}\right]$ concentration. The $\mathrm{pH}$ value of a solution or product represents the present (true) acidity. Normal milk is a slightly acid solution with a $\mathrm{pH}$ falling between 6.5 and 6.7 with 6.6 the most usual value. Temperature of measurement near $25^{\circ} \mathrm{C}$, the $\mathrm{pH}$ is checked with a $\mathrm{pH}$-meter.

2.2.2. Preparation of milk separation: Raw milk must be strained to remove any dirt or particles. Milk must not be cold, homogenized or sour. For best results, separate milk right out of the cows or buffaloes. If that is not possible, rewarm the milk to approximate cow body temperature $38^{\circ} \mathrm{C}$ $\left(100^{\circ} \mathrm{F}\right)$. It is very important that the milk is warm and stays warm 
throughout the separating process. The milk prepared for separation process will warm as follows:

- A tank with approximately 20 liters of water was but over the flame, then the milk container of $10 \mathrm{~kg}$ was place into the water to catch the heat of hot water.

- When the temperature of milk reached about $35-42^{\circ} \mathrm{C}$, it will disburden in the separator vessel slowly.

2.2.3. Separation process: machine operation for separating and removing cream from whole milk is based on the fact that skim milk (milk with no butterfat) is heavier than cream. The separator consists of a centrifuge in the form of a rapidly revolving bowl containing a set of disks shown in Fig.2. The bowl is mounted on a spindle situated underneath the milk supply tank. As milk enters the bowl at the top, it is distributed to the disks through a series of openings in the distributor.

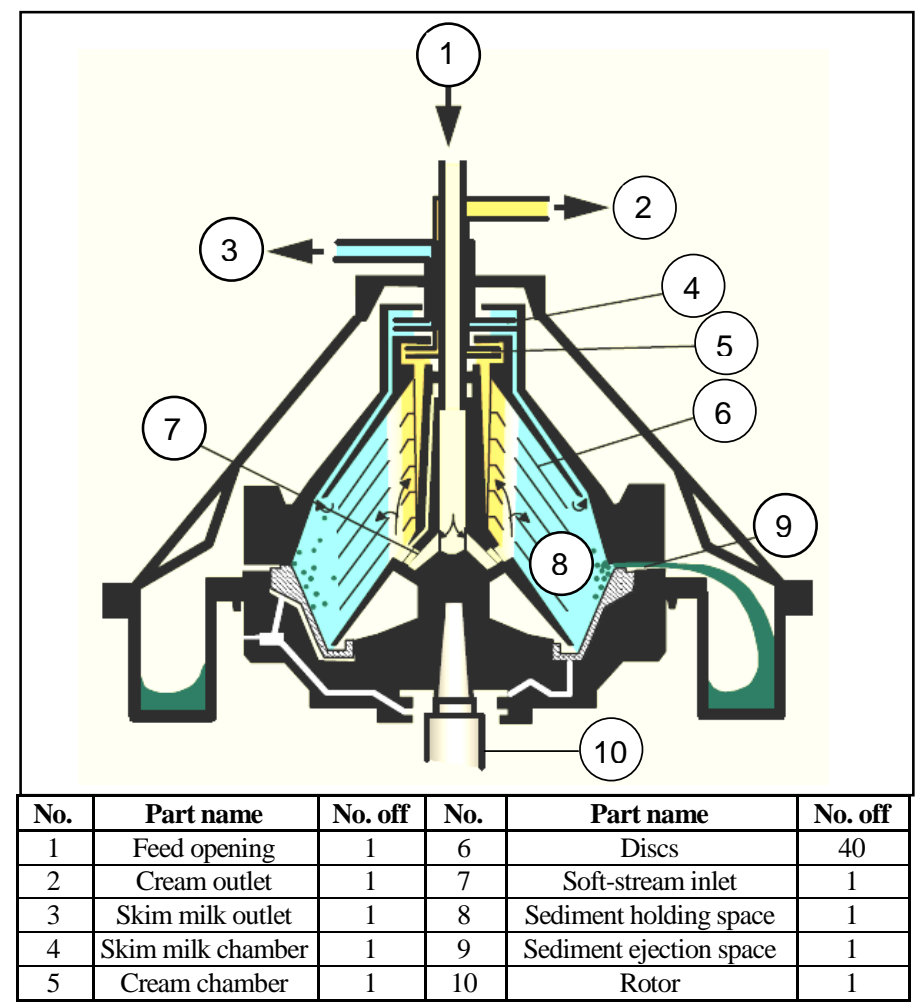

Fig.2. A cross section of the milk centrifugal separator. 
Thin films of milk are generated as whole milk is forced out between the disks; the milk assumes the speed of the bowl, approximately 6000 to 8000 rpm and the heavier skim milk is thrown to the outer edge of the bowl and led off through an opening. The cream concentrates in the interior and moves up to the cream outlet near the center of the bowl. The most efficient separators leave less than 0.01 percent fat in the skim milk.

2.2.4. Separation by centrifugal force: in the dairy industry, in particular, there were cream and cultured milk products which characteristics can be partially or completely spoiled if their flow behavior was not understood. What follows here was a brief guide to the flow behavior of some typical dairy industry products.

2.2.5. Sedimentation velocity: a field of centrifugal force was generated if a vessel was filled with liquid and spun. This creates a centrifugal acceleration. The centrifugal acceleration was not constant like the gravity $g$ in a stationary vessel. The centrifugal acceleration increased with distance from the axis of rotation radius ( $r$ ) and with the speed of rotation, expressed as angular velocity $(\omega)$. The acceleration can be calculated by the formula:

$$
\mathrm{a}=r \omega^{2}, \quad \mathrm{~m} / \mathrm{s}^{2}
$$

Where: $\mathrm{r}=$ radius of separation cone, $\mathrm{m} \quad \omega=$ angular velocity, $\mathrm{rad} / \mathrm{s}$. The following formula was obtained if the centrifugal acceleration was substituted for the gravitational acceleration in Stokes' law equation can be used to calculate the sedimentation velocity (v) of each particle in the centrifuge.

$$
V_{c}=\frac{d^{2}\left(\rho_{s m}-\rho_{f g}\right)}{18 \mu} \cdot r \omega^{2}
$$

Where: $\mathrm{d}=$ diameter of fat globule, $\mathrm{m}$.

$\rho_{\mathrm{sm}}=$ density of the skim milk, $\mathrm{kg} / \mathrm{m}^{3}$.

$\rho_{\mathrm{fg}}=$ density of the fat globules, $\mathrm{kg} / \mathrm{m}^{3}$.

$\mu=$ dynamic viscosity, $\mathrm{kg} / \mathrm{m} . \mathrm{s}$.

2.2.6. Flotation velocity of a fat globule: equation (4) was previously used to calculate the flotation velocity of a single fat globule $3 \mu \mathrm{m}$ in diameter at a radial position of $0.05 \mathrm{~m}$ in a centrifuge rotating at a speed of $\mathrm{N}=8000 \mathrm{rpm}$. The angular velocity can be calculated as: 


$$
\omega=\frac{2 \pi \times \mathrm{N}}{60}, \mathrm{rad} / \mathrm{s}
$$

Where: $\mathrm{N}=$ rotation speed of separation cone, rpm.

Dividing the sedimentation velocity in a centrifugal force field by the sedimentation velocity in a gravity field gives the efficiency of centrifugal separation, compared with sedimentation by gravity. The sedimentation velocity in the centrifuge was $5.92 \times 10^{-4} \mathrm{~m} / \mathrm{s}=0.592$ $\mathrm{mm} / \mathrm{s}$.

2.3.7. Experimental methodology: The present study was conducted to investigate the relation between separation rotating speed of the disc stuck separator, milk feed rate and milk temperature degree and their effect on cream and skim milk amounts, cream and skim milk fat percentage, separation efficiency, specific energy and operational cost.

The centrifugal milk separator was evaluated using the following parameters:

- Milk feed rate: $150,250,350$ and $400 \mathrm{~kg} / \mathrm{h}$.

- Milk temperature: $35,37,40$ and $42{ }^{\circ} \mathrm{C}$.

- Separator rotating speeds: 6000, 7000, 8000 and $9000 \mathrm{rpm}$.

\subsection{MEASUREMENTS AND DETERMINATIONS:}

Evaluation of the performance of the centrifugal milk separator was based on the following indicators:

\subsubsection{Cream amount, $\left(\mathrm{C}_{\mathrm{Am}}\right)$ :}

$$
\mathrm{C}_{\mathrm{Am} .}=\frac{\mathrm{C}_{\mathrm{M}}}{\mathrm{t}}, \mathrm{kg} / \mathrm{h}
$$

Where: $\mathrm{C}_{\mathrm{M}}=$ Mass of cream in the milk sample, $(\mathrm{kg})$.

$\mathrm{t}=$ Time consumed in the separation process, $(\mathrm{h})$.

3.1.2. Skim milk amount, $\left(\mathrm{SM}_{\mathrm{Am} .}\right)$ :

$$
\mathrm{SM}_{\text {Am. }}=\frac{\mathrm{SM}_{\mathrm{M}}}{\mathrm{t}}, \mathrm{kg} / \mathrm{h}
$$

Where: $\mathrm{SM}_{\mathrm{M}}=$ Mass of skim milk in the sample, $(\mathrm{kg})$.

$\mathrm{t}=$ Time consumed in the separation process, $(\mathrm{h})$.

\subsubsection{Cream fat percentage, $\left(C_{F}\right)$ :}

Cream fat percentage was determined according to Gerber's method (1891).

3.1.4. Skim milk fat percentage, $\left(\mathrm{SM}_{\mathrm{F}}\right)$ :

Cream fat percentage was determined according to Gerber's Method (1891). 
PROCESS ENGINEERING

\subsubsection{Separation efficiency, $\left(\eta_{\text {Sep. }}\right)$ :}

$$
\eta_{\text {sep. }}=\frac{\mathrm{C}_{\text {Am. }}}{\mathrm{C}_{\text {Total }}}, \quad \%
$$

Where: $\mathrm{C}_{\text {Total }}=$ Mass of cream in the sample, $(\mathrm{kg})$.

$$
\mathrm{C}_{\text {Total }}=\mathrm{C}_{\mathrm{Am} .}+\mathrm{C}_{\mathrm{L}}
$$

Where: $\mathrm{C}_{\mathrm{L}}=$ Mass of cream loss in the skim milk, $(\mathrm{kg})$.

\subsubsection{Required power, (Po):}

The required power was estimated with the following formula. (Jon Ashby, 1988).

$$
\mathrm{Po}=\sqrt{3} \times \cos \varphi \times \mathrm{I} \times \mathrm{V}
$$

Where: Po $=$ power required, $\mathrm{kW} \quad \mathrm{I}=$ current intensity, Ampere

$$
\mathrm{V}=\text { Voltage, }(380 \mathrm{v}) \quad \cos \varphi=0.70
$$

\subsubsection{Specific energy:}

Specific energy for the separation process can be calculated as follows:

$$
\mathrm{E}_{\mathrm{sp}}=\frac{\mathrm{Po}}{\mathrm{C}_{\mathrm{Am} .}}, \quad \mathrm{kW} \cdot \mathrm{h} / \mathrm{kg}
$$

\subsubsection{Operational cost:}

The operational cost required for the separation process was estimated using the following equation: (Awady, et al. 1982).

$$
\mathrm{C}_{\text {op. }}=\frac{\mathrm{C}}{\mathrm{C}_{\mathrm{Am} .}}, \quad \mathrm{L} . \mathrm{E} / \mathrm{Mg}
$$

Where: $\mathrm{C}=$ Hourly cost, L.E./h.

The hourly cost of milk separator was determined using the following equation: (Awady, 1978).

$$
\mathrm{C}=\frac{\mathrm{p}}{\mathrm{h}}\left(\frac{1}{\mathrm{a}}+\frac{\mathrm{i}}{2}+\mathrm{t}+\mathrm{r}\right)+(\mathrm{W} \cdot \mathrm{e})+\frac{\mathrm{m}}{144}, \quad \mathrm{~L} \cdot \mathrm{E} / \mathrm{h}
$$

Where:

$\mathrm{p}=$ price of machine, $\mathrm{L} . \mathrm{E}$

$\mathrm{h}=$ yearly working hours, $\mathrm{h} /$ year

$\mathrm{a}=$ life expectancy, $\mathrm{h}$.

$\mathrm{i}=$ interest rate/year

$\mathrm{t}=$ taxes, over heads ratio.

$r=$ repairs and maintenance ratio

$\mathrm{W}=$ power of motor in $\mathrm{kW}$. $\mathrm{m}=$ monthly average wage, L.E.

$\mathrm{e}=$ hourly $\operatorname{cost} / \mathrm{kW} \cdot \mathrm{h}$ $144=$ monthly working hours. 


\section{RESULTS AND DISCUSSION}

The obtained results will be discussed under the following items:

\subsection{Influence of separation speed and temperature degree on cream and skim milk amounts:}

Concerning the effect of separation speed, Fig.3 show that increasing separation speed from 6000 to $8000 \mathrm{rpm}$, measured at different feed rates of $150,250,350$ and $400 \mathrm{~kg} / \mathrm{h}$, increased cream amount from 6.33 to 12.00, from 11.90 to 20.38 , from 23.80 to 33.33 and from 24.50 to $35.00 \mathrm{~kg} / \mathrm{h}$, any further increase in separation speed more than 8000 up to $9000 \mathrm{rpm}$ the cream amount decreased from 12.00 to 10.00 , from 20.38 to 17.80 , from 33.33 to 30.50 and from 35.00 to $32.20 \mathrm{~kg} / \mathrm{h}$ at the same previous conditions. On the other hand, increasing separation speed from 6000 to $8000 \mathrm{rpm}$ at the same previous feed rates, the skim milk amount decreased from 143.65 to 138.00 , from 238.10 to 229.60 , from 327.05 to 317.55 and from 375.50 to $365.00 \mathrm{~kg} / \mathrm{h}$, respectively.
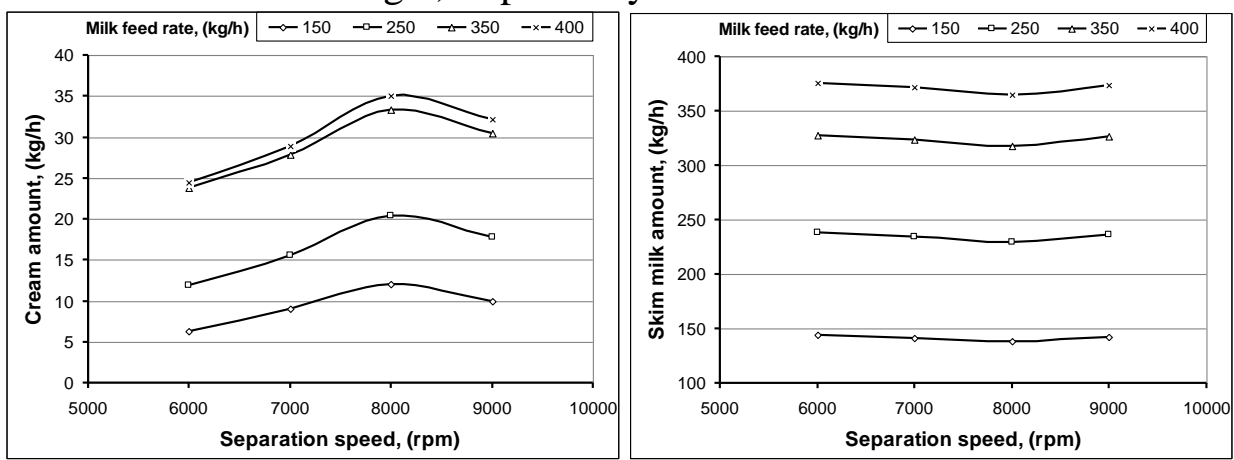

Fig.3. Effect of separation speed on cream and skim milk amounts at different milk feed rates.

While the increases in separation speed from 8000 to $9000 \mathrm{rpm}$, the skim milk increased from 138.00 to 142.35 , from 229.60 to 236.65 , from 317.55 to 326.10 and from 365.00 to $373.60 \mathrm{~kg} / \mathrm{h}$, respectively at constant temperature degree of $37{ }^{\circ} \mathrm{C}$. Higher values of separation speed more than the optimum value tend to decrease cream amount because the time required to separate cream from the milk was inadequate due increasing centrifugal force resulting in less cream amount and more skim milk amount with higher percentage of fat.

Fig.4. shows the effect of temperature degree on cream and skim milk amounts. Increasing in temperature degree from 35 to $37{ }^{\circ} \mathrm{C}$ leads to 
increase cream amount from 8.20 to 12.00 , from 14.30 to 20.38 , from 25.60 to 33.33 and from 27.64 to $35.00 \mathrm{~kg} / \mathrm{h}$. While the skim milk amount decreased from 141.80 to 138.00 , from 235.70 to 229.60 , from 325.25 to 317.55 and from 372.35 to $365.00 \mathrm{~kg} / \mathrm{h}$, respectively. On the other hand, increasing temperature degree from 37 to $42^{\circ} \mathrm{C}$ at the same previous feed rates, the cream amount decreased from 12.00 to 7.30 , from 20.38 to 13.00, from 33.33 to 23.20 and from 35.00 to $24.90 \mathrm{~kg} / \mathrm{h}$, while the skim milk amount increased from 138.00 to 142.70 , from 229.60 to 237.00 , from 317.55 to 327.65 and from 365.00 to 375.10 , respectively at constant separation speed of $8000 \mathrm{rpm}$. Higher values of temperature degree more than the optimum value of $37{ }^{\circ} \mathrm{C}$ tend to decrease cream amount because of increasing the percentage of small fat granules at the expense of the large granules go towards the skim milk to an axial outlet with continues flow, since the smallest fat globules, normally $<1 \mathrm{~mm}$, do not have time to rise at the specified flow rate but are carried out of the separator with the skim milk.
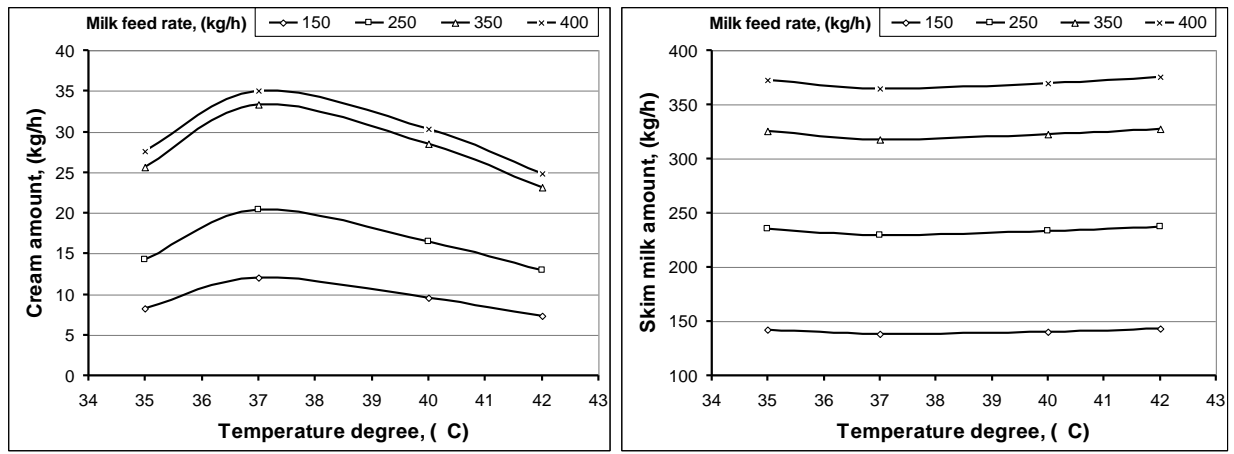

Fig.4. Effect of temperature degree on cream and skim milk amounts at different milk feed rates.

\subsection{Influence of separation speed and temperature degree on cream fat and skim milk fat percentages:}

Considering the effect of separation speed on cream fat and skim milk fat percentages, Fig. 5 indicated that the increase in separation speed from 6000 to $8000 \mathrm{rpm}$ measured at different feed rates of $150,250,350$ and $400 \mathrm{~kg} / \mathrm{h}$, led to increase cream fat percentage from 58 to 68 , from 56 to 66 , from 53 to 60 and from 51 to $58 \%$. While the skim milk fat percentage decreased from 0.30 to 0.05 , from 0.40 to 0.10 , from 0.50 to 0.20 and from 0.70 to $0.40 \%$, respectively. On the other hand, increasing separation speed from 8000 to 
$9000 \mathrm{rpm}$ at the same previous feed rates, the cream fat percentage decreased from 68 to 65 , from 66 to 63 , from 60 to 59 and from 58 to $57 \%$, while the skim milk fat percentage increased from 0.05 to 0.10 , from 0.10 to 0.20 , from 0.20 to 0.30 and from 0.40 to $0.50 \%$, respectively at constant temperature degree of $37^{\circ} \mathrm{C}$.
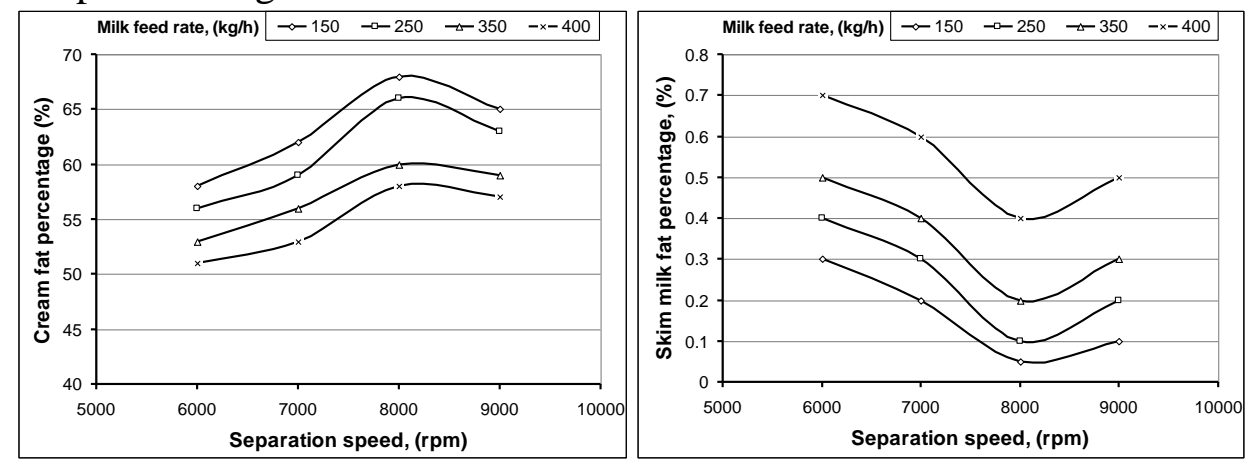

Fig.5. Effect of separation speed on cream fat and skim milk fat percentages at different milk feed rates.

Concerning the effect of temperature degree on cream fat and skim milk fat percentages, Fig.6 shows that increasing temperature degree from 35 to 37 ${ }^{\circ} \mathrm{C}$ measured at different feed rates of $150,250,350$ and $400 \mathrm{~kg} / \mathrm{h}$, increased cream fat percentage from 62 to 68 , from 59 to 66 , from 56 to 60 and from 53 to $58 \%$, any further increase in temperature degree more than $37{ }^{\circ} \mathrm{C}$ up to $42{ }^{\circ} \mathrm{C}$ the cream fat percentage decreased from 68 to 62 , from 66 to 59 , from 60 to 55 and from 58 to $52 \%$ at the same previous conditions. On the other hand, increasing temperature degree from 35 to $37{ }^{\circ} \mathrm{C}$ at the same previous feed rates, the skim milk fat percentage decreased from 0.20 to 0.05 , from 0.30 to 0.10 , from 0.50 to 0.20 and from 0.60 to $0.40 \%$, respectively.
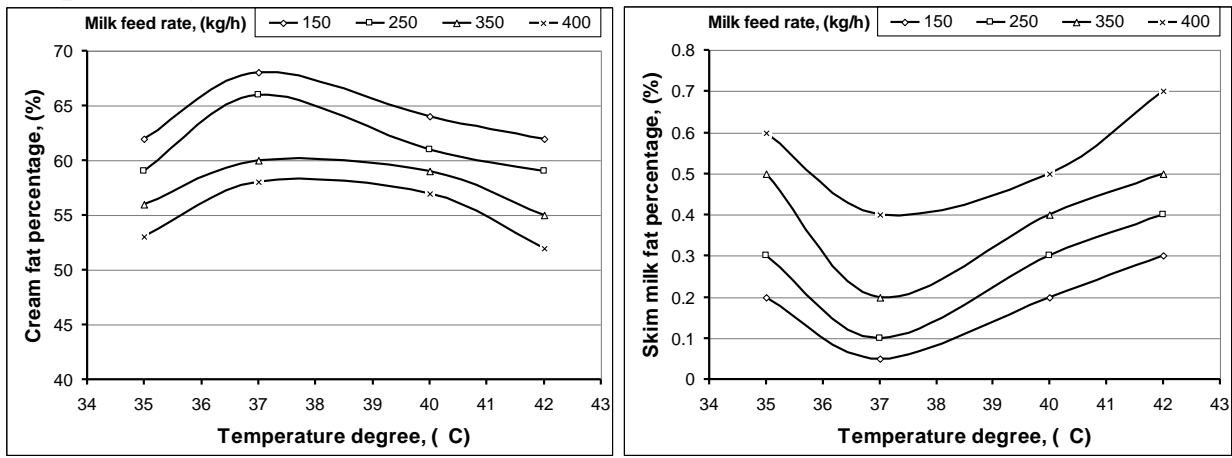

Fig.6. Effect of temperature degree on cream fat and skim milk fat percentages at different milk feed rates. 
While the increases in temperature degree from 37 to $42{ }^{\circ} \mathrm{C}$ the skim milk fat percentage increased from 0.05 to 0.30 , from 0.10 to 0.40 , from 0.20 to 0.50 and from 0.40 to $0.70 \%$, respectively at separation speed of $8000 \mathrm{rpm}$.

\subsection{Influence of separation speed and temperature degree on cream separation efficiency:}

Representative values of separation efficiency for the milk separator versus separation speed and temperature degree at different feed rates are given in Fig.7. With respect to the effect of separation speed, results show that increasing separation speed from 6000 to $8000 \mathrm{rpm}$, measured at different feed rates of $150,250,350$ and $400 \mathrm{~kg} / \mathrm{h}$, increased separation efficiency from 99.49 to 99.93 , from 99.29 to 99.85 , from 99.06 to 99.67 and from 98.64 to $99.32 \%$, consecutively. Any further increase in separation speed more than $8000 \mathrm{rpm}$ up to $9000 \mathrm{rpm}$ at the same feed rates decreased the separation efficiency from 99.93 to 99.85 , from 99.85 to 99.68 , from 99.67 to 99.49 and from 99.32 to $99.13 \%$, respectively at constant temperature degree of $37^{\circ} \mathrm{C}$.
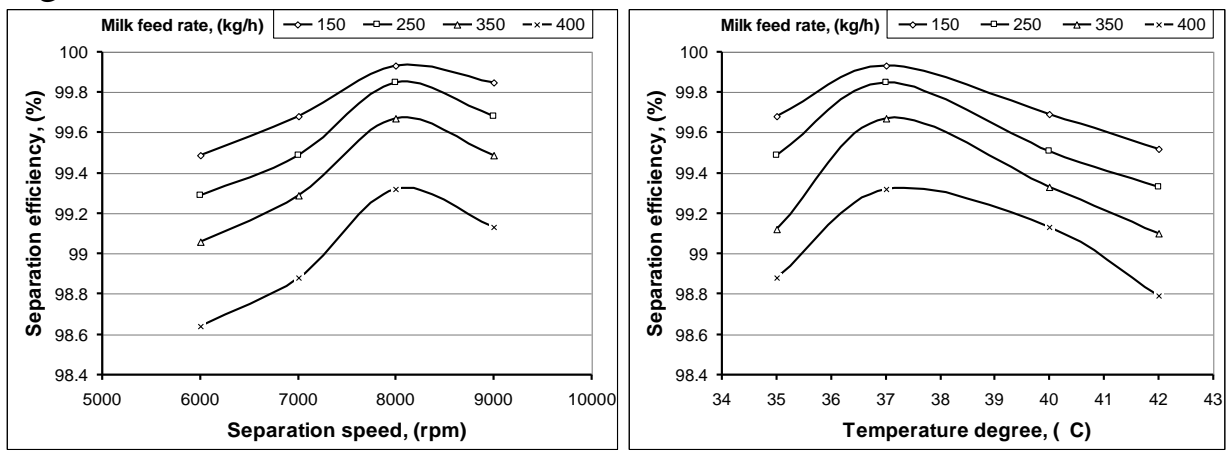

Fig.7. Effect of separation speed and temperature degree on separation efficiency at different milk feed rates.

With respect to the effect of temperature degree, results in Fig. 7. show that increasing temperature degree from 35 to $37{ }^{\circ} \mathrm{C}$ measured at different feed rates of $150,250,350$ and $400 \mathrm{~kg} / \mathrm{h}$, increased separation efficiency from 99.68 to 99.93 , from 99.49 to 99.85 , from 99.12 to 99.67 and from 98.88 to $99.32 \%$, consecutively. In spite of increasing temperature degree from 37 to $42{ }^{\circ} \mathrm{C}$, measured at the same previous feed rates, decreased separation efficiency from 99.93 to 99.52 , from 99.85 to 99.33 , from 99.67 to 99.10 and from 99.32 to $89.79 \%$, respectively, at constant separation speed of $8000 \mathrm{rpm}$. The highest value of separator efficiency of $99.93 \%$ was 
recorded at the optimum values of separation speed of $8000 \mathrm{rpm}$ and temperature degree of $37{ }^{\circ} \mathrm{C}$ because of they give the fat globules at the suitable time to rise and be discharged through the cream outlet. Under this condition the skim milk fat percentage was decreased at the lowest value of $0.05 \%$.

\subsection{Influence of separation speed and temperature degree on specific energy:}

Concerning the effect of separation speed, Fig.8 show that increasing separation speed from 6000 to $8000 \mathrm{rpm}$, measured at different feed rates of $150,250,350$ and $400 \mathrm{~kg} / \mathrm{h}$, decreased specific energy from 139.02 to 73.33 , from 73.95 to 43.18 , from 36.97 to 26.40 and from 35.92 to $25.14 \mathrm{~kW} . \mathrm{h} / \mathrm{Mg}$, any further increase in separation speed more than 8000 up to $9000 \mathrm{rpm}$ the specific energy increased from 73.330 to 88.00 , from 43.18 to 49.44 , from 26.40 to 28.85 and from 25.14 to $27.21 \mathrm{~kW} . \mathrm{h} / \mathrm{Mg}$ at constant temperature degree of $37^{\circ} \mathrm{C}$.
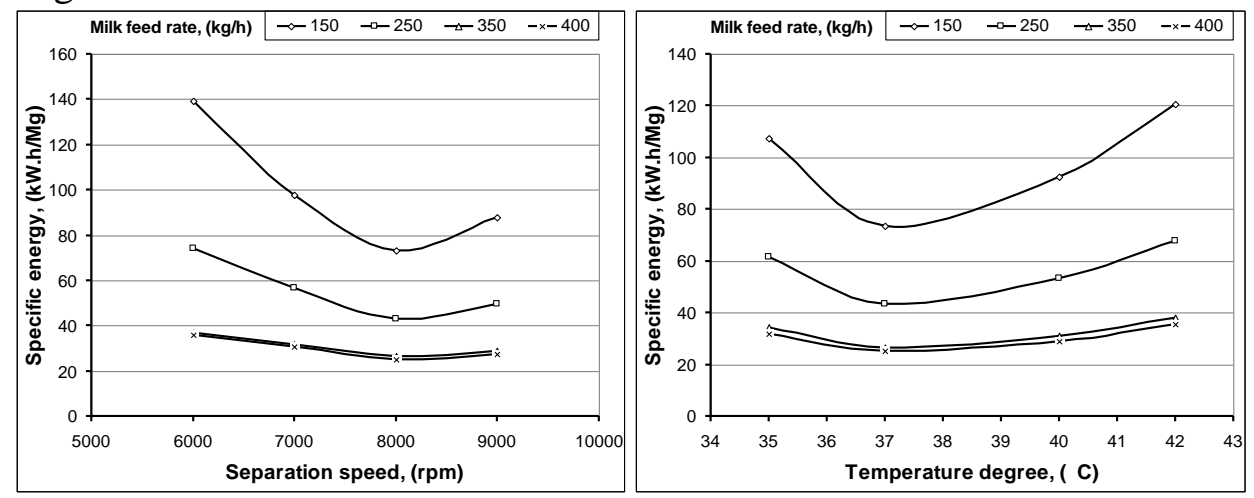

Fig.8. Effect of separation speed and temperature degree on specific energy at different milk feed rates.

With respect to the effect of temperature degree on specific energy, results in Fig. 8 show that increasing temperature degree from 35 to $37{ }^{\circ} \mathrm{C}$ measured at different feed rates of $150,250,350$ and $400 \mathrm{~kg} / \mathrm{h}$, decreased specific energy from 107.31 to 73.33 , from 61.54 to 43.18 , from 34.38 to 26.40 and from 31.84 to $25.14 \mathrm{~kW} . \mathrm{h} / \mathrm{Mg}$, respectively. In spite of increasing temperature degree from 37 to $42{ }^{\circ} \mathrm{C}$, measured at the same previous feed rates, the specific energy increased from 73.33 to 120.55 , from 43.18 to 67.69, from 26.40 to 37.93 and from 25.14 to $35.34 \mathrm{~kW} . \mathrm{h} / \mathrm{Mg}$, respectively, at constant separation speed of $8000 \mathrm{rpm}$. The higher values of separation 
speed and temperature degree more than the optimum value tend to increase the specific energy due to decrease cream amount or separator production.

\subsection{Influence of separation speed and temperature degree on operational cost:}

Relating to the effect of separation speed on operational cost. Fig. 9 shows that increasing separation speed from 6000 to $8000 \mathrm{rpm}$, measured at different feed rates of $150,250,350$ and $400 \mathrm{~kg} / \mathrm{h}$, decreased operational cost from 1263.80 to 666.70 , from 672.30 to 392.50 , from 336.10 to 240.00 and from 326.50 to $228.60 \mathrm{~L} . \mathrm{E} / \mathrm{Mg}$, any further increase in separation speed more than 8000 up to $9000 \mathrm{rpm}$ the operational cost increased from 666.70 to 800.00 , from 392.50 to 449.40 , from 240.00 to 262.30 and from 228.60 to 248.40 L.E/Mg at constant temperature degree of $37^{\circ} \mathrm{C}$.
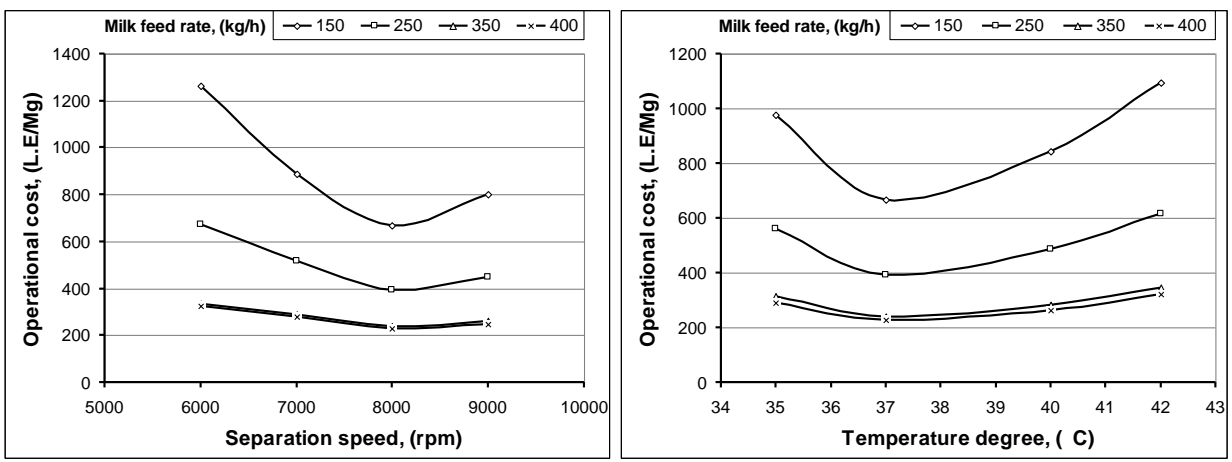

Fig.9. Effect of separation speed and temperature degree on operational cost at different milk feed rates.

Concerning the effect of temperature degree on operational cost, Fig.79 shows that increasing temperature degree from 35 to $37{ }^{\circ} \mathrm{C}$ measured at different feed rates of $150,250,350$ and $400 \mathrm{~kg} / \mathrm{h}$, decreased operational cost from 975.60 to 666.70 , from 559.40 to 392.50 , from 312.50 to 240.00 and from 289.40 to $228.60 \mathrm{~L} . \mathrm{E} / \mathrm{Mg}$, any further increase in temperature degree more than $37{ }^{\circ} \mathrm{C}$ up to $42{ }^{\circ} \mathrm{C}$ the operational cost increased from 666.70 to 1095.90 , from 392.50 to 615.40 , from 240.00 to 344.80 and from 228.60 to $321.30 \mathrm{~L} . \mathrm{E} / \mathrm{Mg}$ at constant separation speed of $8000 \mathrm{rpm}$. Both higher and lower values of separation speed and temperature degree more than or less to the optimum values tend to increase operational cost due to the decrease the separator productivity. 


\section{CONCLUSION}

A milk separator for skimming milk was manufactured from locally available materials in a private workshop in Zagazig city and evaluated at Agricultural Engineering Department and Food Science Department under laboratory conditions. The obtained laboratory tests reveal that the cream amount value was at maximum of $35 \mathrm{~kg} / \mathrm{h}$, while the specific energy and operational cost were at minimum of $25.14 \mathrm{~kW} . \mathrm{h} / \mathrm{Mg}$ and $228.60 \mathrm{~L} . \mathrm{E} / \mathrm{Mg}$, respectively under the following conditions:

- Milk feeding rate to the conical separating unit of $400 \mathrm{~kg} / \mathrm{h}$.

- Separation rotating speed of $8000 \mathrm{rpm}$.

- Temperature degree of the raw milk of $37^{\circ} \mathrm{C}$.

\section{REFERRENCES}

Aita, O. A. A., Shadia E. S. Elshishini, Fatheya A. H. Soliman and Samah R. M. Shaalan (2012): Best Available Techniques (BAT) for the Dairy Industry in Egypt. Final report. http://databases.bat4med.org/.

Awady, M. N. (1978): Tractor and farm machinery. Text book, Faculty of Agriculture, Ain-Shams University. Pp: 164-167.

Awady, M. N; E. Y. Ghoniem, and A. I. Hashish (1982): Agriculture comparison between wheat combine harvesters under Egyptian conditions. Res. Bul. Ain-Shams Univ.:13p.

DMI (2005): Cream Ingredients. Dairy Management Inc. $^{\text {TM }}$. www.innovatewithdairy.com.

Endress and Hauser (2008): Promag and Promass provide fat standardization with precise control of cream's density and flow. www.us.endress.com.

Gerber, N. (1891): Neuer Butyrometer. Patent CH2621, (1891-01-31), Bern: Eidgenössisches Institut für Geistiges Eigentum.

John G. Ashby (1988): Power Hydraulics. PAVIC Publications.

K. J. Burgess (1991): Milk Fat, Society of Dairy Technology, Huntingdon, U. K., pp. 30-36.

Kenanaonline (2013): Fat Products. www.kenanaonline.net/page/8626.

Meshref A. M. S. (2013): Bacteriological quality and safety of raw cow's milk and fresh cream. Slov. Vet Res. 50 (1): 21-30. 
Tetra Centri (2003): Tetra Centri dairy separators for every duty. Tetra Pak Processing Components AB, Lund, Sweden. www.tetrapak.com.

Westfalia, GEA (2010): Process stages, systems and equipment for the dairy industry from GEA Westfalia Separator. www.westfaliaseparator.com.

Westfalia, GEA (2012): Milk Fat Processing. Machines used for making butter oil. www.westfalia-separator.com.
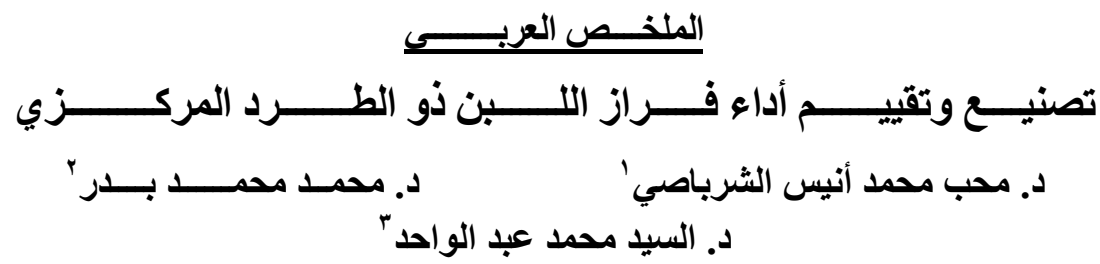

يعتبر اللبن غذاءً كاملاً ومهماً للصحة فهو يحوي كل العناصر الغذائية ذات الطبيعة الخاصة مثل فل التهل

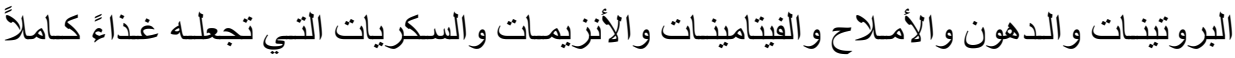
ووظيفياً في نفس الوقت. وتعنبر قشدة اللبن هي الطبقة التي تتكون فوق سطح اللبن ونتركز فيها

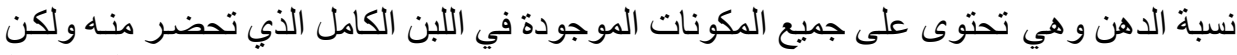

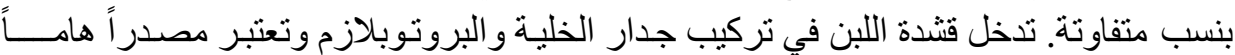

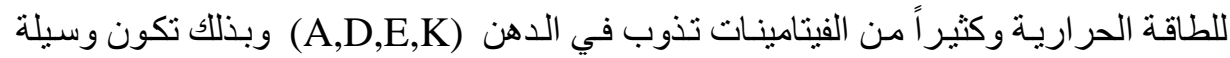

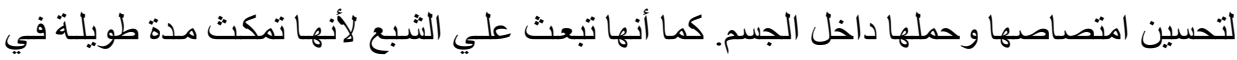

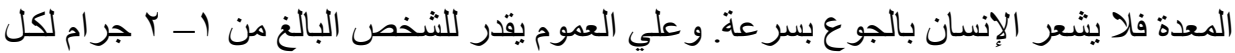

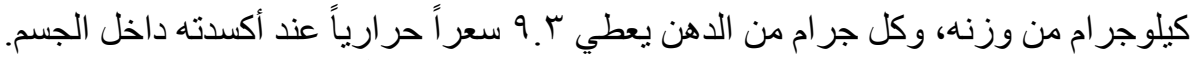

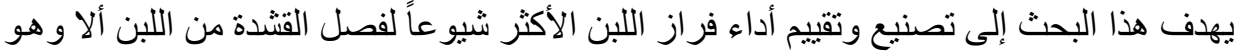

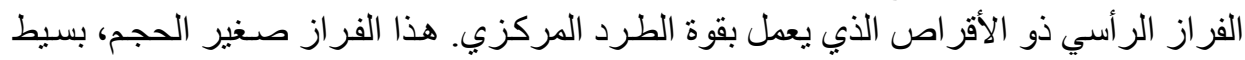

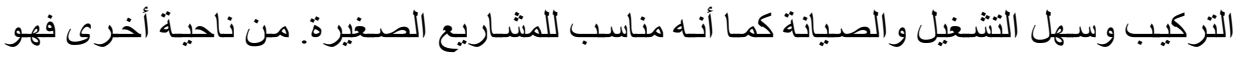
يساعد على التغلب على مشكلة الفرز اليدوي (طريقة الترقيد) التي ماز الت موجودة في معظم

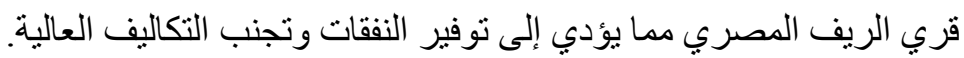

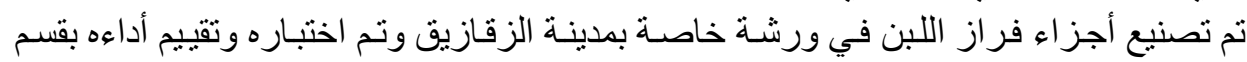

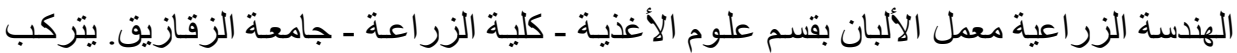
فر از اللبن من الأجزاء الآتية:-

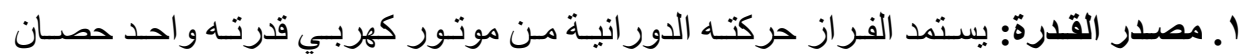

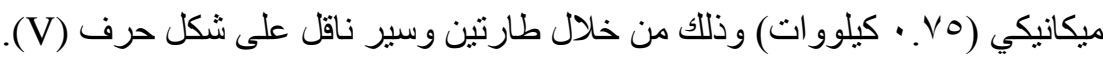

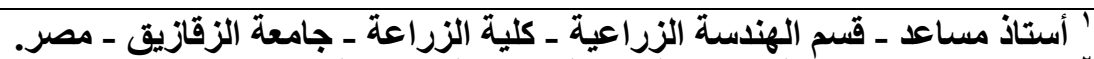

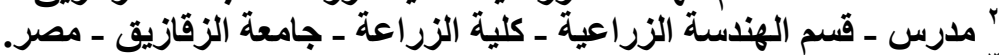

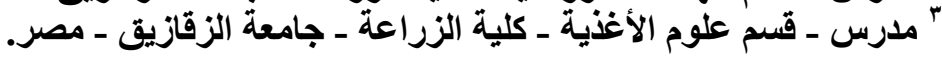




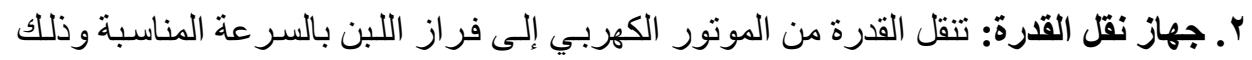

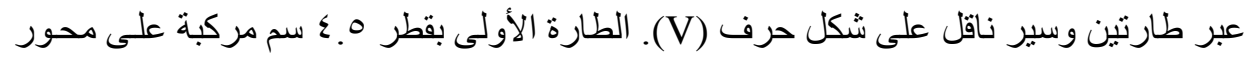
عمود

الموتور الكهربي، والطارة الثانية بقطر • • 10 سم مركبة على محور عمود الفراز.

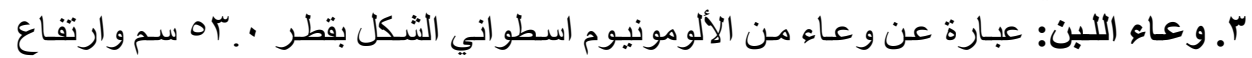

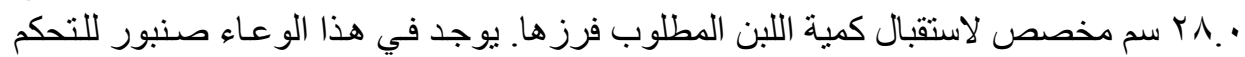

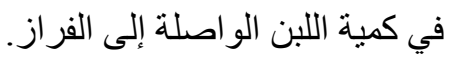
ع. وحدة الفرز (الفصل): تتكون وحدة الفرز مـن ثلاثـة أجز اء رئيسية هي: (القاعدة) وهي

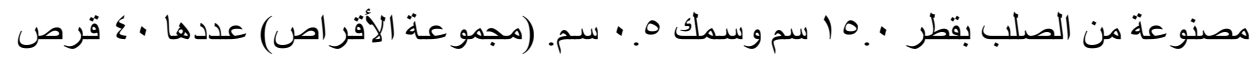
مخروطية الشكل بقاعدة كبرى لأسفل قطر ها • .0 أسم وقاعدة صغرى قطر ها . .0 سم وارتفاع

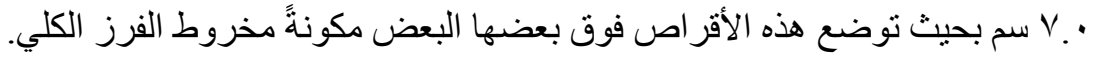
وكل قرص يحتوي على ثنلاث ثقوب بقطر · . أسم في الجزء العلوي على محيط القرص.

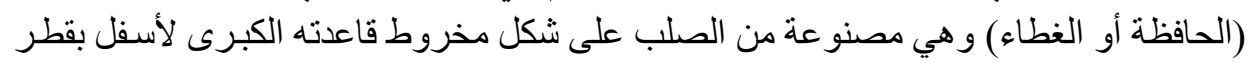

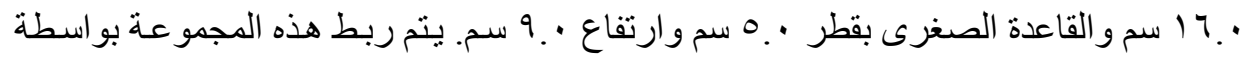

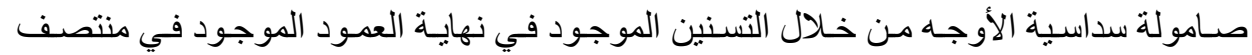
القرص الأول من أسفل. تم در اسـة عدد من المتغير ات لتقييم فر از اللبن بعد التصنيع و التركيب و التي تشـمل استخدام

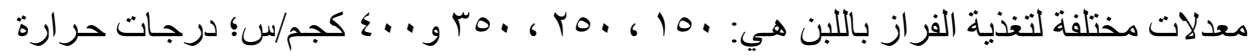

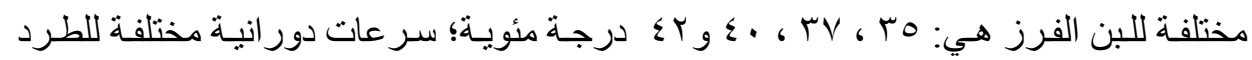

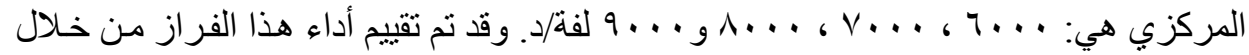

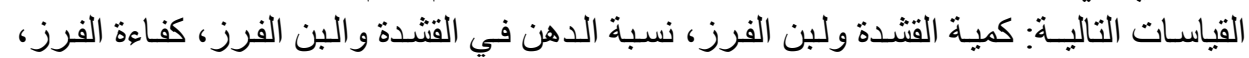
الطاقة النوعية المستهلكة وتكاليف التشغيل اللازمة لعملية الفرز لكل ميجا جر ام من اللبن.

\section{وقد أظهرت النتائج المتحصل عليها ما يلي:}

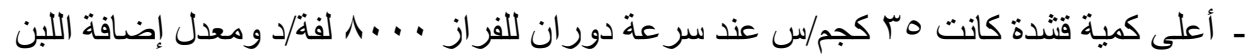

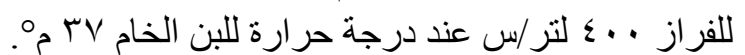

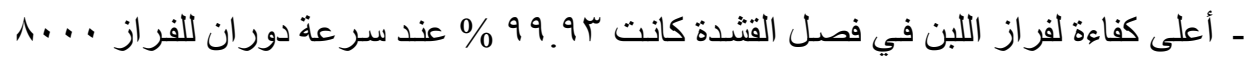

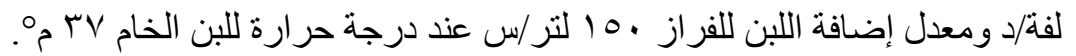

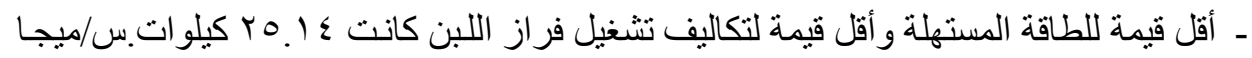

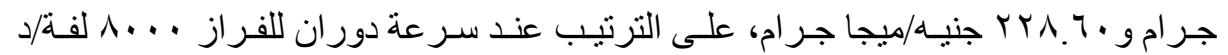

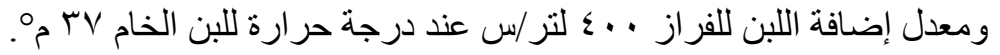

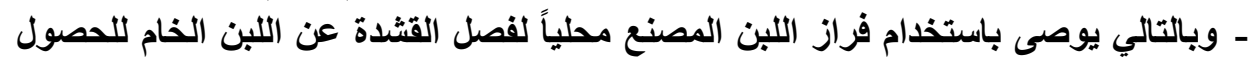

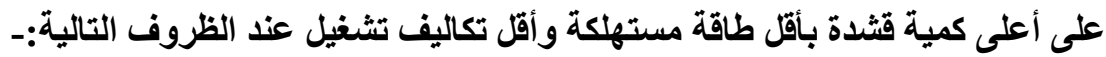

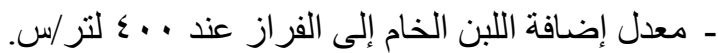

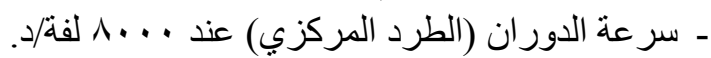
ـ درجة حر ارة اللبن الخام عند Vr مّ. 